\title{
INTRODUKSI SISTEM BIOFLOCK PADA USAHA BUDIDAYA LELE UNTUK MENINGKATKAN PENDAPATAN MASYARAKAT DI DESA PERING, KECAMATAN BLAHBATUH, KABUPATEN GIANYAR
}

\author{
B.R.T. Putri ${ }^{1}$, I.D.P. Singarsa ${ }^{2}$, N.L.M. Pradnyawathi ${ }^{2}$, dan N.N. Yastini ${ }^{3}$
}

\begin{abstract}
ABSTRAK
Desa pering merupakan salah satu dari sembilan desa yang terdapat di Kecamatan Blahbatuh, Kabupaten Gianyar. Desa Pering yang dikenal sebagai salah satu desa pemasok ikan air tawar untuk wilayah Denpasar dan sekitarnya. Terdapat beberapa kelompok tani ikan yang telah berkembang di Desa Pering, salah satunya adalah kelompok tani ikan "Sari Mekar". Salah satu komoditas air tawar yang biasa dibudidayakan di Desa Pering adalah lele, yang dipelihara secara konvensional dengan menggunakan kolam tanah. Kelompok tani ikan "Sari Mekar" telah berhasil melakukan budidaya lele dengan baik, namun belum mampu memasok kebutuhan lele secara kontinu setiap harinya, karena keterbatasan lahan dan modal yang dimiliki. Salah satu cara yang dapat dilakukan adalah budidaya lele dengan menggunakan sistem bioflock. Kegiatan introduksi sistem bioflock pada usaha budidaya lele kelompok tani ikan "Sari Mekar" dilakukan pada tanggal 29 Agustus 2017, yang dilanjutkan dengan pelatihan pembuatan kolam lele, demoplot budidaya lele, dan pendampingan. Hasil kegiatan ini menunjukkan bahwa introduksi sistem bioflock pada usaha budidaya lele di kelompok tani ikan "Sari Mekar" telah berjalan dengan sangat baik, terlihat dari antusiasme kelompok untuk segera menerapkan sistem bioflock pada usaha budidaya lele yang mereka lakukan.
\end{abstract}

Kata kunci : desa pering, budidaya lele, bioflock, introduksi, sistem

\begin{abstract}
Pering village is one of nine villages in Blahbatuh sub-district, Gianyar regency. Pering village is known as one of the village of fish supplier for Denpasar and its surrounding area. There are several fish farming groups that have grown in Pering Village, one of them is the "Sari Mekar" fish farming group. One of the fish commodities commonly cultivated in Pering Village is catfish, which is conventionally maintained using a traditional pool. Fish farming group "Sari Mekar" has successfully cultivated catfish well, but has not been able to supply the needs of catfish continuously every day, due to limited land and capital owned. One way that can be done is the cultivation of catfish by using bioflock system. The introduction of bioflock system on fish farming cultivation of "Sari Mekar" fish farming group was conducted on August 29, 2017, followed by training of catfish pond production, catfish cultivation demoplot, and assistance. The results of this activity indicate that the introduction of bioflock system on the cultivation of catfish in the fish farming group "Sari Mekar" has been running very well, seen from the enthusiasm of the group to immediately apply the bioflock system on their catfish cultivation business.
\end{abstract}

Keywords: pering village, cultivation of catfish, bioflock, introduction, system

\footnotetext{
${ }^{1}$ Fakultas Peternakan Universitas Udayana : tanama_putri@yahoo.com

${ }^{2}$ Fakultas Pertanian Universitas Udayana

${ }^{3}$ Fakultas Pertanian Universitas Dwijendra
} 


\section{PENDAHULUAN}

Kecamatan Blahbatuh merupakan salah satu kecamatan dari 7 kecamatan yang ada di Kabupaten Gianyar, berbatasan dengan Kecamatan Blahbatuh di sebelah timur, Kecamatan Ubud di sebelah utara, dan di sebelah selatan berbatasan dengan Laut Bali serta Kota Denpasar di sebelah Barat. Secara geografis Kecamatan Blahbatuh terletak antara 08¹9'408" - 08 29'38" Lintang Selatan, $115^{\circ} 15^{\prime} 19^{\prime \prime}$ - 115 $19^{\prime} 50^{\prime \prime}$ Bujur Timur. Kecamatan Blahbatuh Kabupaten Gianyar, berada pada ketinggian antara 0 - $450 \mathrm{~m}$ dpl dengan luas wilayah 1760,384 ha.

Desa pering merupakan salah satu dari 9 desa yang terdapat di Kecamatan Blahbatuh, Kabupaten Gianyar. Jumlah penduduk Desa Pering sebanyak 7938 jiwa tergabung dalam 1587 KK terdiri atas 3960 laki-laki dan 3969 perempuan, dengan mata pencaharian penduduk sebagian besar adalah bertani, diikuti oleh jasa perdagangan, peternakan, dan perikanan. Kebutuhan lele untuk kota Denpasar dan sekitarnya sebanyak 4.000 ton/hari, dan belum bisa terpenuhi oleh petani ikan di Bali. Kelompok tani ikan "Sari Mekar" telah berhasil melakukan budidaya lele dengan baik, namun belum mampu memasok kebutuhan lele secara kontinu setiap harinya, karena keterbatasan lahan dan modal yang dimiliki. Selain keterbatasan lahan dan permodalan, peternak juga memiliki kekhawatiran untuk melakukan budidaya lele dalam skala besar dalam kondisi cuaca yang cukup ekstrim dengan perbedaan suhu siang dan malam yang cukup tinggi, serta hujan yang tidak menentu.

Berdasarkan permasalahan yang ada dan dikaitkan dengan RPJM Pemerintah Daerah Gianyar, maka perlu dicarikan suatu alternatif budidaya lele yang efektif dan efisien untuk diterapkan sehingga mampu menghasilkan produksi lele yang baik secara kontinu setiap harinya. Salah satu cara yang dapat dilakukan adalah budidaya lele dengan menggunakan sistem bioflock.

\section{METODE PELAKSANAAN}

Berdasarkan permasalahan yang dihadapi oleh kelompok tani ikan "Sari Mekar" yang ada di Desa Pering, Kecamatan Blahbatuh, Kabupaten Gianyar, maka metode yang diterapakan adalah:

1. Melakukan penyuluhan tentang sistem bioflock pada budidaya ikan lele, dengan tahapan kegiatan sebagai berikut:

a. Memberikan penjelasan mengenai sistem bioflock

b. Penjelasan mengenai alat, bahan, serta ukuran standar kolam yang dibutuhkan dalam membuat kolam budidaya lele sistem bioflock

c. Penjelasan mengenai cara pembuatan flok pada kolam budidaya lele sistem bioflock

d. Penjelasan mengenai cara pemeliharaan dan penanganan masalah pada kolam budidaya lele dengan sistem bioflock

2. Mengadakan pelatihan dan praktek dalam membuat kolam budidaya lele dengan sistem bioflock

3. Mengadakan praktek budidaya lele dengan sistem bioflock

4. Memberikan pendampingan dalam budidaya lele sistem bioflock.

\section{HASIL DAN PEMBAHASAN}

Kegiatan introduksi sistem bioflock pada usaha budidaya lele diawali dengan sosialisasi dan koordinasi pelaksanaan program kepada pihak Pemda dan OPD (Organisasi Pelaksana Daerah) terkait. Sosialisasi dilaksanakan pada tanggal 2 Juni 2017 bertempat di kantor Bappeda Kab. Gianyar. Tujuan kegiatan sosialisasi ini adalah untuk menyampaikan program kegiatan yang akan dilaksanakan kepada pihak Pemkab Gianyar yang kemudian dapat disinkronisasikan tentang program dan waktu yang ada pada OPD terkait. Sosialisasi ini berjalan lancar dan mendapat tanggapan yang baik dari Pemerintah Kabupaten Gianyar. 
Selanjutnya pada tanggal 7 Juli 2017 dilakukan survei lokasi, untuk menentukan kelompok masyarakat yang mau dan mampu untuk melaksanakan kegiatan. Berdasarkan hasil survei dan wawancara dengan beberapa kelompok masyarakat, maka kelompok terpilih adalah kelompok tani ikan "Sari Mekar" dengan komoditas lele (Clarias gariepinus).

Kegiatan penyuluhan dan pelatihan tentang sistem bioflock dilaksanakan pada tanggal 29 Agustus 2017 di Desa Pering, Kecamatan Blahbatuh, Kabupaten Gianyar, dengan peserta sebanyak 26 orang berasal dari kelompok tani ikan "Sari Mekar". Materi yang disampaikan pada kegiatan penyuluhan adalah memberikan penjelasan mengenai kelemahan sistem budidaya lele konvensional, yaitu kurangnya kemampuan petani untuk mengontrol kualitas air kolam, diantaranya suhu, supplay oksigen, dan limbah mikroorganisme (Effendi, 2003). Selain itu, sisa pakan tambahan dapat meningkatkan kandungan amoniak pada media budidaya, yang dapat memicu tingginya tingkat kematian (Craigh dan Helfrich, 2002).

Sistem bioflock merupakan salah satu alternative teknologi yang dapat diterapkan pada usaha budidaya lele untuk mengatasi masalah keterbatasan lahan dan kualitas media budidaya. Menurut Schryver et al. (2008) system bioflock adalah suatu sistem budidaya bakteri heterotrof dan alga dalam suatu gumpalan flocs dan dikembangbiakkan secara terkontrol dalam suatu wadah budidaya.

Aplikasi teknologi bioflock pada usaha budidaya lele dapat berperan dalam perbaikan kualitas air, meningkatnya biosekuriti, meningkatkan produktivitas, meningkatkan efisiensi pakan serta mampu menurunkan biaya produksi melalui penurunan biaya pakan (Avnimelech, 2007; Ekasari, 2008; Hari dkk., 2006; Taw, 2008). Menurut Setiawan,dkk. (2016), aplikasi system bioflock mampu memberikan pertumbuhan lele yang lebih baik dibandingkan dengan menggunakan system konvensional. Penerapan system bioflock ini mampu mengatasi masalah keterbatasan lahan dalam upaya intensifikasi budidaya lele. Pengaplikasian system bioflock pada usaha budidaya lele mampu mengurmengurangi penggantian air atau bahkan tidak dilakukan penggantian air sama sekali, sehingga system bioflock merupakan teknologi budidaya yang ramah lingkungan.

Kegiatan penyuluhan ini dilanjutkan dengan pelatihan pembuatan empat buah kolam bulat dengan ukuran D2T1 untuk demoplot budidaya lele dengan sistem bioflock. Kolam dibuat dengan keranga besi berbentuk bulat, yang kemudian dilapisi dengan terpal untuk memudahkan pembersihan kolam (Gambar. 1).

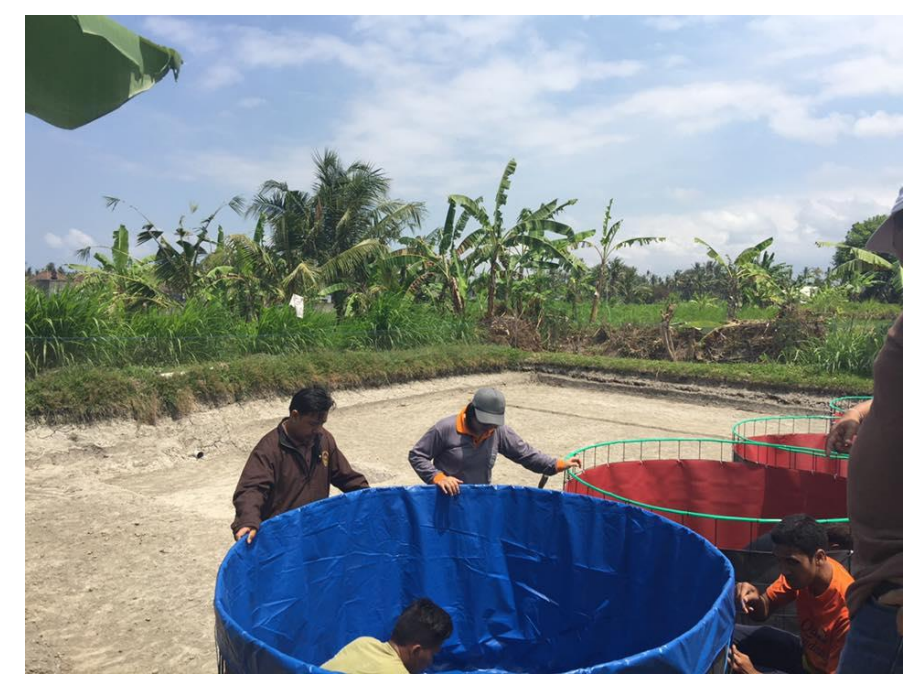

Gambar 1. Pelatihan pembuatan kolam lele sistem bioflock.

Tahapan budidaya lele diawali dengan fermentasi air kolam dengan menambahkan campuran pupuk hayati cair, probiotik, dan molase kedalam air kolam, kemudian dibiarkan selama \pm 7 hari 
Introduksi Sistem Bioflock pada Usaha Budidaya Lele untuk Meningkatkan Pendapatan Masyarakat di Desa Pering, Kecamatan Blahbatuh, Kabupaten Gianyar

sampai air berubah warna menjadi cokelat. Selanjutnya dilakukan penebaran benih lele (Clarias gariepinus) umur 50 hari, sebanyak 1.500 ekor pada masing-masing kolam. Pemeliharaan lele dilakukan selama 3 bulan.
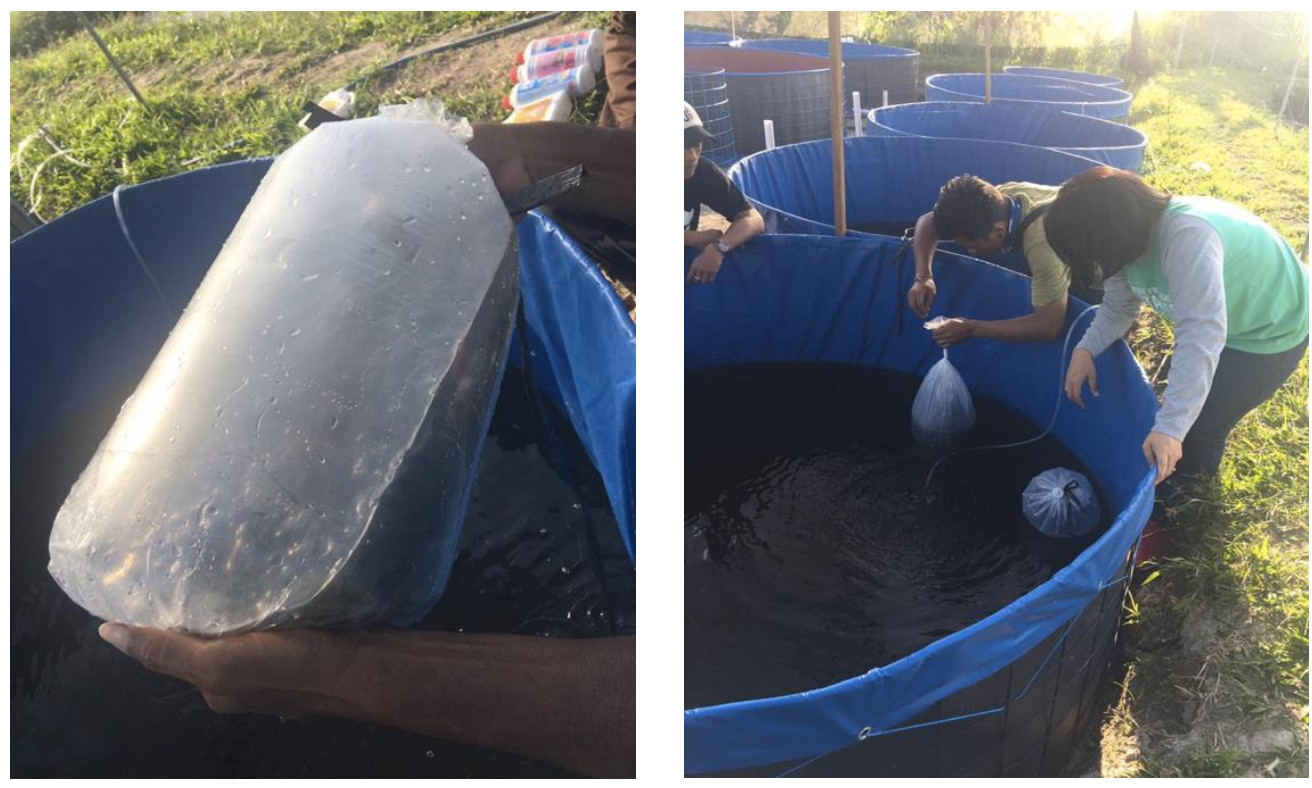

Gambar 2-3. Penebaran bibit lele umur 50 hari

Respon anggota kelompok tani ikan "Sari Mekar" pada kegiatan pengabdian kepada masyarakat ini sangat baik, terlihat dari atusiasme anggota kelompok dalam menerapkan ilmu tentang sistem bioflock pada usaha budidaya lele dengan menambah jumlah kolam yang akan digunakan untuk budidaya lele dengan sistem bioflock (Gambar 4).

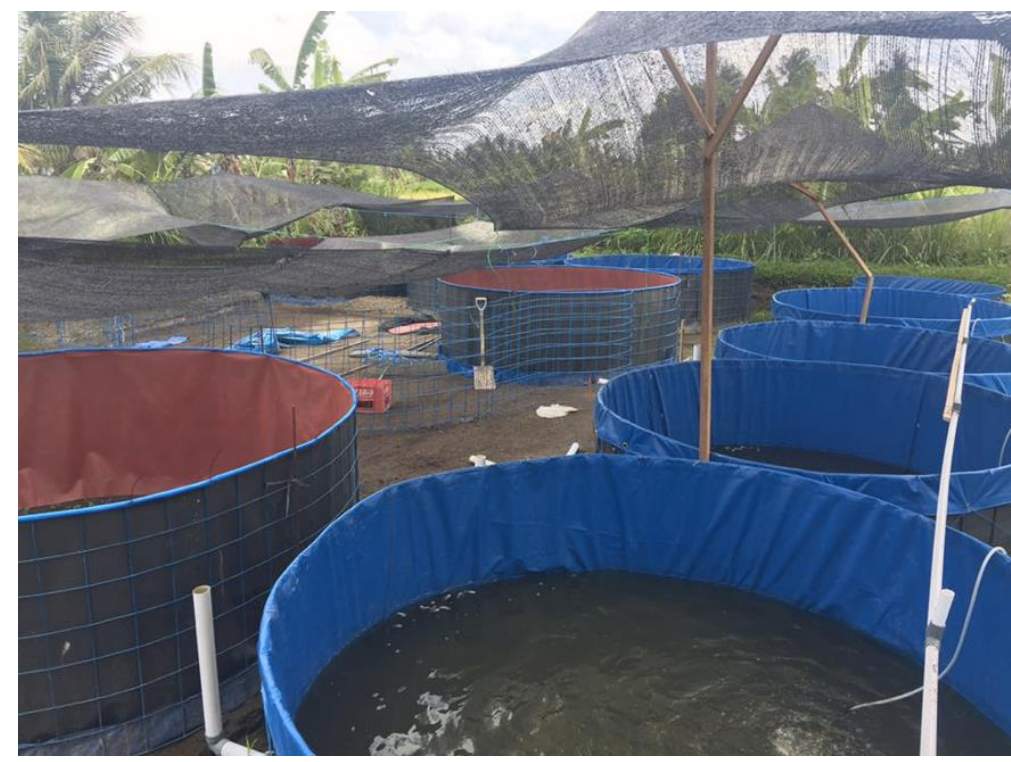

Gambar 4. Penambahan kolam secara swadaya oleh anggota kelompok. 
Kegiatan pendampingan dilakukan secara intensif antara tim pelaksana kegiatan dengan anggota kelompok, baik dari segi sharing informasi teknis mengenai tata cara buddaya lele dengan sistem bioflock, maupun solusi tentang penanganan berbagai masalah yang dihadapi.

\section{KESIMPULAN DAN SARAN}

\section{Simpulan}

Dari hasil kegiatan yang telah dilakukan dapat disimpulkan bahwa kegiatan pengabdian kepada masyarakat yang dilakukan pada kelompok tani ikan "Sari Mekar" telah berjalan dengan baik, intensitas komunikasi antara pelaksana kegiatan dengan anggota kelompok yang cukup tinggi untuk mendiskusikan tentang penerapan sistem bioflock, serta antusiasme anggota kelompok untuk segera menerapkan budidaya lele dengan sistem bioflock yang ditunjukkan dengan aksi nyata yaitu segera membuat kolam sesuai dengan arahan tim pengabdi.

\section{Saran}

Kegiatan pengabdian kepada msyarakat kali ini masih terfokus pada upaya perbaikan sistem budidaya untuk peningkatan pendapatan petani ikan. Diharapkan untuk kegiatan-kegiatan selanjutnya, dapat merambah pada sektor hilir yaitu pengolahan lele dan pemasarannya untuk meningkatkan value added dari produk lele yang dihasilkan, sehingga pendapatan petani ikan dapat terus ditingkatkan.

\section{UCAPAN TERIMAKASIH}

Ucapan terimakasih kami sampaikan kepada: Direktorat Jenderal Riset dan Pengembangan Kementerian Riset, Teknologi, dan Pendidikan Tinggi Republik Indonesia yang telah mendanai kegiatan pengabdian kepada masyarakat ini, kepada Rektor dan Ketua Lembaga Penelitian dan Pengabdian kepada Masyarakat Universitas Udayana, terima kasih atas bantuan fasilitas yang telah diberikan sehingga kegiatan pengabdian kepada masyarakat ini dapat terlaksana dengan baik. Kepada kelompok tani ikan "Sari Mekar", dan seluruh pihak yang terlibat dalam kegiatan ini kami ucapkan terima kasih atas kerjasama yang telah terjalin dengan baik.

\section{DAFTAR PUSTAKA}

Avnimelech Y. \& Kochba M., 2009, Evaluation of nitrogen uptake andexcretion by tilapia in bio floc tanks, using $15 \mathrm{~N}$ tracing. Aquaculture 287:163-168.

Craigh S. \& Helfrich LA., 2002, Understanding Fish Nutrition, Feeds, and Feeding, Viginia Coperative Extension Service. Publication 420-256: 1-4

Ekasari J. ,2008, Bioflocs technology: the effect of different carbon source, salinity and the addition of probiotics on the primary nutritional value of the bioflocs. Thesis. Faculty of Bioscience Engineering. Ghent University. Belgium.

Effendi MI., 2003, Biologi Perikanan. Bandung: Yayasan Pustakan Nusantara.

Hari B, Kurup BM, Varghese JT, Schrama JW, \& Verdegem MCJ., 2006, The effect of carbohydrate addition on water quality and the nitrogen budget in extensive shrimp culture sistems.

Schryver PD, Crab R, Defoirdt T, Boon N, \& Verstraete W., 2008, The basics of bio- flocs technology: The added value for aquaculture. Aquaculture 277: 125-137.

Taw N, Fuat J, Tarigan N, \& Sidabutar K., 2008, Partial harvest/biofloc sistem promising for Pacific white shrimp. Global Aquaculture Advocate Magazine. September/ October 2008: 84-86.

Setiawan, A., Ariqoh,R., Tivani,P., Pipih,L., dan Pudjiastuti,I. 2016. "Bioflukasi Sistem" Teknologi BUdidaya Lele Tebar Padat Tinggi Dengan Kapasitas $1 \mathrm{M}^{3} / 750$ Ekor Dengan Flock Forming Bacteria. Inovasi Tekknik Kimia. Vol. 1. No.1, Hal 45-49. 